\title{
Власть и город: к вопросу о самоорганизации общественности в российских городах. Конец XIX - начало XX вв.
}

\begin{abstract}
Аннотачия. В статъе рассматривается одна из ключевъх проблем общественно-культурной жизни пореформенного города: гражданская активность, самоорганизачия общественности и влияние коронной администрачии, во многом определявшей появление и степень развития различных форм общественной самодеятельности. Исследование основано на материалах российского города, в котором - как наиболее креативном сочиокультурном организме - возникали эти явления. Изучение этих аспектов общественной жизни в известной степени позволяет решить вопрос о возможности формирования гражданского общества в дореволючионной России. Взаимоотношения города и власти закреплялись законами 1870 и 1892 г2. Самоорганизачия городской общественности происходила в условиях, когда город стремился к изменению характера отношений с администраиией и получению большей самостоятельности в решении проблем своей жизни. Револючия 1905 г. и Первая мировая война способствовали росту гражданской иниииативы, а также тому, ито власть пошла на некоторые уступки городу под влиянием требований общественности. Предреволючионные десятилетия были временем консолидачии общественных сил и появления новых форм их организачии. Существовавшее противодействие офиииальной власти этому прочессу определило безуспешность диалога власти и общества.
\end{abstract}

Ключевые слова: пореформенный город, коронная администрачия, Городовые положения, формы самоорганизаиии общественности, местное самоуправление, избирательное право, проекты городской реформы, революиия, Первая мировая война, Всероссийский союз городов.

Abstract. This article addresses one of the key questions regarding the socio-cultural life of the post-reform town: civic engagement, community self-organization, and the influence of the crown administration that in many ways determined the appearance and the level of development of various forms of social initiatives. The research is based on materials from Russian towns in which occurred these phenomena - the town being the most creative of all socio-cultural organisms. The study of these aspects of social life substantially helps to resolve the question of whether it was possible to form a civic community in pre-Revolutionary Russia. The relationship between government and towns was secured by legislation in 1870 and 1892. The self-organization of town community happened under conditions when towns sought to change the nature of their relations with the central administration and to receive more autonomy in resolving their problems. The revolution of 1905 and the First World War contributed to the growth of civic engagement, and also to the government making some concessions to towns under the influence of society's demands. The pre-Revolutionary decade was a time of the social forces' consolidation and the appearance of new forms of their organization. The existing opposition of the official authorities to this process determined the failure of the "dialogue" between government and society.

Key words: revolution, projects of town reform, electorial right, local self-government, forms of community self-organization, Regulation of Towns, crown administration, post-reform town, First World War, All-Russian Union of towns.

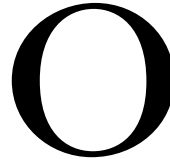

дной из основных проблем, привлекающих внимание современных ученых-гуманитариев, являются различные формы самодеятельности, гражданской активности, самоорганизации общественности $[1 ; 2 ; 3 ; 4 ; 5 ; 6]$. Возможность изучения этой проблемы заложена в рамках новой социальной истории, методологические принципы которой предполагают более детальный многоуровневый социальный анализ исторических явлений, чем это имело место в марксистской историографии. Данная методология характеризуется расширением внимания к социальным проблемам, выявлением качественно новых аспектов в самом понятии социального, одним из которых являются формы социализа- 


\section{Исторический журнал: научные исследования № 4 (28) • 2015}

DOI: $10.7256 / 2222-1972.2015 .4 .17038$

ции человека. Отсюда вытекает актуальность изучения таких проблем, как степень активности человека в общественной жизни, появление различных форм общественной самоорганизации, факторы, влиявшие на развитие гражданской активности.

Эти явления общественной жизни тесно связаны и в известной степени определяют возможности зарождения, уровень развития и состояние гражданского общества в дореволюционной России.

Статья основана на материалах российского города конца XIX - начала XX вв., в котором как наиболее креативном социально-культурном организме - проявились эти процессы.

Самоорганизация общественности в пореформенном российском городе происходила в условиях, когда город в лице органов общественного управления стремился к изменению взаимоотношений с правительственной администрацией, законодательно закрепленных Городовыми положениями 1870 и 1892 гг., и к получению большей самостоятельности в решении проблем развития муниципального хозяйства, городского благоустройства.

Степень самостоятельности действий городских властей определяла возможность появления и развития системы местного самоуправления. В исследуемый период эта проблема становилась предметом обсуждения в общественных и научных кругах. Помимо самого факта внимания к проблеме местного самоуправления, росло понимание значения этого социального института для развития общественно-политической системы в стране. Один из исследователей общественного городского хозяйства Москвы, редактор журнала «Самоуправление» М. П. Щепкин писал в 1906 г., что «местное самоуправление составляет основу нашей новой гражданственности». При этом он считал, что «в основе конституционного устройства страны должно лежать самоуправление, служащее наилучшей подготовительной школой для трудной, сложной и ответственной работы народных представителей в парламенте» [7, III].

В пореформенной России вплоть до 1917 г. правовые нормы взаимоотношений города и правительства в лице губернатора определялись законами, изданными в 1870 и 1892 гг. (далее ссылки на статьи этих законов даны в тексте в круглых скобках) $[8 ; 9 ; 10 ; 11]$.

Приоритетность политического фактора в становлении российского города Нового времени объективно предполагала наличие административной опеки, которую город всегда испытывал. В реальной жизни речь шла лишь о возможном ее ограничении.

Основными вопросами, которые поднимала городская общественность на протяжении всего пореформенного времени, включая начало XX в., были: ограничение контроля правительства в лице губернатора за действиями городских властей, внесение изменений в избирательную систему и распространение избирательного права на городскую интеллигенцию (так называемых квартиронанимателей), наконец, получение большей финансовой самостоятельности при формировании городского бюджета [6].

Эти вопросы возникали уже в период подготовки Городового положения 1870 г. Созданные по инициативе правительства многочисленные комиссии, которые работали в 60-е гг. XIX в., высказывались о необходимости смягчения «крайне стеснительной правительственной опеки», об «отсутствии самостоятельности во всех главнейших действиях по городскому хозяйству и благоустройству» $[12,4]$.

Правительство выслушивало мнение общественности, но далеко не всегда учитывало его в своих действиях. Общий правительственный курс в плане взаимоотношения власти и общественного городского управления принципиально не изменился. И тем не менее современники оценивали городскую реформу 1870 г. как проникнутую «духом либерализма», «типичное произведение эпохи Великих реформ» [13, 9].

Реформа, несомненно, положительно повлияла на жизнь города: была создана включавшая представительную и исполнительную структуры (городская дума и управа) система городского управления, просуществовавшая до 1917 г., городские власти получили право самостоятельного расходования средств на начальную школу, «народное здравие», а также на увеличение расходов на пожарное и санитарное дело, городское благоустройство.

Но вопросы, волновавшие общественность, сохранились. «Умеренный либерализм» закона 1870 г., разрешая самостоятельные действия городских властей, существенно ограничивал эту самостоятельность. Сферой их действия было муниципальное хозяйство, причем заниматься этими проблемами можно было лишь «в пределах одного города» (ст. 4, 5). Даже в период реформаторской деятельности пра- 
Социальная история

DOI: $10.7256 / 2222-1972.2015 .4 .17038$

вительства и общественной активности 18601870-х гг. город в лице своих руководителей был лишен права участия в общественно-политической жизни страны. Административный контроль сохранялся: по закону 1870 г. губернатор осуществлял «надзор за законным исполнением действий городских властей» (ст. 1).

Городовое положение 1870 г. вводилось постепенно и только к середине 1880-х гг. приобрело силу закона для всех городов Европейской России. Но уже в начале этого десятилетия принципиальные положения городской реформы стали предметом обсуждения и в обществе, и в правительстве. Либеральный курс министра внутренних дел М. Т. Лорис-Меликова, поддержанный Александром II, предполагал дальнейшее реформирование органов местного общественного управления в земстве и городе. Комиссии, созданные при Министерстве внутренних дел, занимались подготовкой материалов для возможных в будущем реформ. Обсуждение законодательных актов, в том числе и Городового положения 1870 г., с целью возможного изменения, уточнения некоторых принципиальных положений в этих законах в известной степени можно рассматривать как факт внимания правительства к мнению общественности.

После событий 1 марта 1881 г. и смерти императора Александра II правительство стало более осторожно, если не сказать отрицательно, относиться к проявлению общественной активности. Местное самоуправление не приветствовалось новым императором. На всеподданнейших отчетах губернаторов довольно часты были такие пометки Александра III: «пресловутое самоуправление», «нелепость городского самоуправления российских городов» [14, 253]. Губернаторы, которые по закону 1870 г. «надзирали» за деятельностью городских властей, в ответах на циркуляр министра внутренних дел, разосланный в 1884 г., были единодушны в том, что «городские общественные учреждения пользуются слишком широкой самостоятельностью и независимостью от местной администрации» [14, 212-213].

В официальном общественном мнении, выразителем которого в 1880-е гг. были «Московские ведомости» М. Н. Каткова, также преобладало убеждение в «излишней» самостоятельности органов местного общественного управления. «У нас возникло фальшивое воззрение, - отмечалось в одной из корреспонденций, - порожденное быстротой реформ минувшего царствования, о каких-то самостоятельных в государстве и от него независимых властях <..> которые должны существовать не только отдельно <...> но в существенной оппозиции к правительству - земские, городские учреждения» [15, 186-187].

В такой политической атмосфере возможность самоорганизации общественности сокращалась, а гражданская активность падала. Террористическая деятельность радикальных слоев по отношению к представителям верховной власти создавала неприемлемые условия для диалога правительства с обществом и, несомненно, влияла на позицию правительства по вопросу об избирательных правах городской интеллигенции. В официальных документах неоднократно высказывалось мнение, что участие в органах городского управления представителей интеллигенции повлечет «ненужные радикальные последствия» $[16,42]$.

Несмотря на изменение общественно-политической обстановки в стране, правительство не отказалось от предполагаемого еще Лорис-Меликовым обсуждения проблем местного управления. Была образована Особая комиссия для составления проектов преобразования местного управления под председательством товарища министра внутренних дел М. С. Каханова, известная как Кахановская комиссия. (Примечательно, что к ее работе, инициированной Министерством внутренних дел, Д. А. Толстой, возглавлявший это министерство, относился негативно.) Работа Комиссии продолжалась в течение 1881-1885 гг. [14,6].

Созданная в системе правительственных структур Кахановская комиссия продолжила традицию обсуждения проектов и издания законодательных актов без широкого привлечения общественности. Членами ее были сенаторы, директор хозяйственного департамента, чиновники Министерства внутренних дел. Общественность представляли предводители дворянства некоторых губерний. Из числа руководителей городского управления в заседаниях участвовал только городской голова Петербурга (П. Л. Корф, затем - сменивший его И. И. Глазунов). Вопросы местного городского управления были второстепенными в работе Кахановской комиссии. Основное внимание уделялось проблемам земства. Члены комиссии исходили из того, что права города по закону 1870 г. были определены «с исчерпывающей полнотой» и коренного изменения 


\section{Исторический журнал: научные исследования № 4 (28) • 2015}

DOI: 10.7256/2222-1972.2015.4.17038

«дарованных городам прав самоуправления» не требовалось [14, 192-195].

Однако городское законодательство стало предметом обсуждения в заседаниях комиссии. Это были все те же «коренные» проблемы: права и финансы города, изменения в избирательной системе и увеличение субъектов избирательного права за счет городской интеллигенции.

Демократизм избирательной системы является важным фактором самоорганизации общественных сил, развития гражданской активности. Характер избирательного права, определявшего степень участия горожан в выборах гласных в городскую думу, имел первостепенное значение в развитии местного самоуправления. Поэтому правительство рассматривало избирательное право в качестве важнейшего инструмента, с помощью которого можно было регулировать процесс формирования органов местного управления, определять рамки этого процесса. Неслучайно на протяжении всего пореформенного времени расширение социального поля применения избирательного права было одним из главных вопросов, которые ставила общественность перед властью.

Уже современники, исследователи городского самоуправления в России, отмечали, что «избирательная система была наиболее слабым местом реформы 1870 г.», что это было «недоверием к молодым общественным силам, особенно - наиболее демократическим элементам города» $[13,13]$.

В 1890-е гг. в числе некоторых законодательных мер правительства Александра III, peформировавших систему местного управления (закон о земских начальниках, земская реформа), было принято Городовое положение 1892 г. Издавая этот закон, правительство опиралось на «пожелания» общественности, рекомендации представителей власти, губернаторов, которые, в частности, высказывались в Кахановской комиссии. Однако только те мнения, которые отражали интересы власти, были учтены и законодательно оформлены в новом положении. «Городская реформа, - отмечал один из ученых-правоведов того времени, - подготавливалась в “тиши министерских канцелярий”, без какого-либо общественного обсуждения, широкой гласности, которая сопровождала принятие Городового положения 1870 г.» [12, 18]. На характере принятия решений сказывалась общая общественно-политическая обстановка в стране, в которой правительство пыталось проводить преобразования.

Социальный состав членов общественного городского управления, несомненно, влиял на характер взаимоотношений коронной администрации с властями города. Поэтому в законе 1892 г. не были учтены пожелания общественности об изменении избирательной системы. Закон не только сохранил прежнюю регламентированность норм избирательного права, но и усилил принцип сословности в избирательной системе. При сохранении доминирования имущественного ценза для получения избирательного права новый закон отдавал предпочтение владельцам недвижимой собственности, среди которых преобладали дворяне.

Это было вызвано беспокойством правительства по поводу того, что закон 1870 г. на практике не обеспечил широкого участия дворянства в качестве гласных в городских думах. «Общественность, провозглашенная реформой 1870 г., - отмечал В. М. Гессен, - оказалась недостаточно благонадежной и заменялась (имеется в виду закон 1892 г. - Л. К.) усилением дворянского элемента в городском общественном управлении» $[17,115]$. Правда, несмотря на предпринятые правительственные меры, радикальных изменений в сословно-социальном составе гласных городских дум не произошло: купцы и почетные граждане преобладали в органах городского общественного управления. В условиях модернизации социально-экономической жизни, роста капитала позиции торгово-промышленного класса, прежде всего - представителей крупной буржуазии, неизбежно укреплялись, что не могло не сказаться на их более значительном присутствии в городских думах [18, 37]. В Московской городской думе в 1896 г. среди гласных дворяне составляли 24,2\%, в то время как купцы и почетные граждане - 68,3\%, мещане и крестьяне - 7,5\% [19, 212].

Другим «исправлением» избирательной системы стало ограничение числа горожан, владевших активным избирательным правом, т. е. правом участия в выборах гласных. Сокращение круга избирателей по закону 1892 г. достигалось введением имущественного ценза, определяемого стоимостью недвижимой собственности. Необходимый ее минимум был разным: в столицах он составлял 3 тыс. руб., в наиболее крупных губернских городах - 1,5 тыс. руб., в прочих губернских и значительных уездных городах 1 тыс. руб., в остальных городских поселениях - 
Социальная история

DOI: $10.7256 / 2222-1972.2015 .4 .17038$

300 руб. Лица, не владевшие таким капиталом, лишались избирательных прав и отстранялись от участия в выборах (ст. 24). Увеличением минимума имущественного ценза правительство усилило антидемократизм избирательной системы. От участия в выборах, а следовательно, в общественной жизни города, фактически отстранялась основная масса горожан, среди которых преобладали мелкобуржуазные слои, мещанство. Число участвовавших в выборах резко уменышалось. В Петербурге и Москве, например, число избирателей по закону 1870 г. составляло 21 тыс., а в 1892 г. - только 7-8 тыс. [20, 19].

В соответствии с Городовым положением 1892 г. уменьшение числа горожан, обладавших активным избирательным правом, по сравнению с 1870 г., происходило по всем городам. В среднем по губернским городам их доля в процентах снизилась в 5 раз (см. таблицу 1; в таблице использованы подсчеты В. А. Нардовой [18, 20-21]).

Таблииа 1

Горожане, имевшие право голоса (от числа жителей в \%)

\begin{tabular}{|l|c|c|}
\hline \multicolumn{1}{|c|}{ Город } & $\mathbf{1 8 7 0}$ г. & $\mathbf{1 8 9 2}$ г. \\
\hline Петербург & 1,9 & 0,6 \\
\hline Москва & 4,4 & 0,7 \\
\hline Саратов & 5,0 & 0,9 \\
\hline Тула & 4,9 & 1,2 \\
\hline Ярославль & 8,0 & 0,9 \\
\hline Орел & 4,6 & 1,1 \\
\hline Рязань & 5,0 & 1,3 \\
\hline
\end{tabular}

«По Городовому положению 1870 г., - отмечалось в 1911 г. в журнале "Городское дело", - городская беднота имела в городской думе своих представителей. В 1892 г. всех этих приказчиков, лавочников и мелких ремесленников, выбиравших одну треть гласных, выбросили за борт; самих выборных лиц, стоявших во главе самоуправления, превратили в чиновников» [21, 472].

«Закон 1892 г., - констатировал К. А. Пажитнов, - внес такое ограничение избирательного права и такое вмешательство со стороны администрации, каких не знает ни одно цивилизованное государство» $[22,42]$. Наряду с введением высокого имущественного ценза ограничение числа избирателей произошло вследствие нежелания правительства распространить избирательное право на квартиронанимателей, составлявших значительный социальный слой в городе, - городскую интеллигенцию. В 1892 г. они, как и по закону 1870 г., избирательных прав не получили. При обсуждении Городового поло- жения 1892 г. в Государственном совете причина отклонения рекомендации Кахановской комиссии о расширении избирательного права оставалась прежней и объяснялась опасением властей, что «от введения квартиронанимателей в думы деятельность этих учреждений будет направлена на ложный путь увлечений как хозяйственного, так и политического свойства» [22, 34].

Отсутствие демократизма в формировании органов городского общественного управления отстраняло основную массу горожан от участия в общественной жизни города и не способствовало развитию гражданской инициативы и активности. А именно эти факторы лежали в основе самоорганизации общественности. Гражданская инертность выражалась, в частности, в слабом участии горожан, имевших право голоса, в избирательной кампании. И. Х. Озеров связывал это участие с проблемами «широкого самоуправления, с хорошей организацией избирательного права». «Наша избирательная система, - отмечал он, - отдает управление в руки небольшой кучки, <...> естественно, пропадает интерес к участию в выборах» [20, 17]. В Москве, например, в 1900 г. в выборах участвовали 26,2\% горожан, имевших право голоса, в 1904 г. - только 20,8\%. В 1900 г. в Мюнхене (Германия) в выборах принимали участие более $68 \%$, в Вене (Австрия) - 60,5\% горожан, имевших право голоса $[20,18]$.

В 1890-е гг. система городских органов распорядительной и исполнительной власти осталась прежней. Но их деятельность была поставлена под усилившийся административный контроль, который не способствовал самостоятельности действий городских властей. В законе 1892 г., в отличие от прежнего закона, отсутствовало даже упоминание о такой самостоятельности. Если в Городовом положении 1892 г. функция общественного управления определялась как «ведение дела о местных пользах и нуждах» (ст. 1), то в законе 1870 г. было указано, что «в пределах предоставленной власти (попечения и распоряжения по городскому хозяйству и благоустройству) городские органы действуют самостоятельно» (ст. 1, 5).

Губернаторский контроль уже выходил за рамки только «надзирания». По закону 1892 г. губернатор определял «правильность» и «целесообразность» решений городской думы. Он получил право останавливать выполнение решения думы, если оно, по его мнению, противоречило «общим государственным пользам и 


\section{Исторический журнал: научные исследования № 4 (28) • 2015}

\section{DOI: $10.7256 / 2222-1972.2015 .4 .17038$}

нуждам» (ст. 83). Таким образом, вмешательство представителя административной власти в работу распорядительного органа общественного городского управления основывалось уже не на законе (в 1870 г. ссылка на «несоответствие закону» была), а на субъективном восприятии с его стороны правильности таких действий.

По закону 1892 г. городское управление теряло общественный характер и становилось казенным учреждением. Городской голова, работники городской управы считались лицами, «состоящими на государственной службе». Власть контролировала работу городской управы: комиссии, создаваемые управой, могли «отправлять свои обязанности не иначе как с разрешения губернатора», который мог «производить ревизию управ и других исполнительных органов общественного управления» (ст. 7, 101, 121).

В 1890-е гг. в законодательном акте исчезает само понятие «городское общество», и появляется термин «городское поселение». Город рассматривается властью как административная единица, а не определенное сообщество граждан. (Понятие «градское общество» впервые появилось в 1785 г. в Жалованной грамоте городам, данной Екатериной II.)

После издания Городового положения 1892 г. в среде общественности, ученых, публицистов существовало довольно распространенное мнение, что «у нас вообще не оставалось самоуправления в общественном смысле слова». [22, 40]; «городское самоуправление, подобно земскому, понесло большой ущерб в отношении своей самостоятельности. Сильно было сокращено число гласных, а всего важнее то, что городские управы были поставлены в значительной мере в непосредственную зависимость от коронной администрации» [23, 114].

Таким образом, правовые нормы, определявшие взаимоотношение административной власти и общественных органов городского управления, с изданием Городового положения 1892 г. значительно ограничили возможность развития гражданской активности. Превращение органов городского управления из общественных фактически в казенные учреждения исключало возможность оппозиции власти, выражение несогласия с действиями администрации. Это порождало общественную инерцию, усиливало «равнодушное и безразличное отношение городского общества к городскому делу» $[12,26]$.

Городовое положение 1892 г. было основным законом, определявшим в конце XIX и пер- вые десятилетия ХХ вв. сферу деятельности городских властей и степень контроля коронной администрации за этой деятельностью. И практически в течение всего этого времени не утихала критика закона 1892 г.

Отношение к действующему закону было важным фактором в процессе самоорганизации городской общественности. Основными проблемами, требовавшими изменений в городском законодательстве, как и прежде, оставались избирательное право, отмена административной опеки и расширение финансовой самостоятельности городских властей - «вот те три главные заветные двери, - указывалось в журнале "Городское дело", - замки с которых пришло время сбить и открыть их заждавшемуся русскому обществу». Для реализации этой программы прогрессивной общественности, как отмечалось в передовой статье «Городского дела», были «нужны новые настроения и устремления в самом обществе» $[24,159]$. В реальной жизни эти «устремления», несомненно, существовали. Например, были ходатайства о необходимости внесения изменений в действующий закон, появившиеся уже в первые годы после его принятия. В 1896-1898 гг. мещанские общества УстьСысольска, Хвалынска, Сызрани ходатайствовали о понижении имущественного ценза «для увеличения гласных из мещан». Но эти ходатайства были «оставлены без уважения». Активность городской общественности в отношении критики Городового положения 1892 г. усилилась в первые десятилетия ХХ в. Большинство ходатайств относится к этому времени. Костромская, Камышинская городские думы высказывались за расширение избирательного права, за отказ от имущественного ценза как основного условия для получения горожанами (не только мужчинами, но и женщинами) права участия в выборах. Правда, женщины при этом не могли занимать должности по городскому управлению. Ответы министра внутренних дел на все эти просьбы были постоянны: оставить «без удовлетворения», «без уважения», «отклонить» $[6$, 502-503]. Городские власти выступали с инициативой расширения участия в жизни города, не ограничивая свои действия только хозяйственной сферой. В заседаниях городских дум поднимались вопросы городского законодательства и критики действующего закона. В выступлениях гласных Петербургской городской думы (Г. А. Фальборка, М. М. Ковалевского и др.) говорилось, например, об «антиобщественном Го- 
родовом положении», необходимости расширения компетенции городского управления, которая должна больше «включать заботу о местных пользах и нуждах». Псковская городская дума в 1915 г. выступила с инициативой «возбуждения вопроса о немедленной городской реформе», признав необходимым «развитие просвещения и широкое привлечение всех слоев населения к местному самоуправлению» $[6,505]$.

Тот факт, что город нуждался в расширении «прав и средств», понимало и правительство, которое, как и городская общественность, признавало «несоответствие Городового положения 1892 г. нынешним условиям наших городов». Однако пределы изменений в этом законодательстве, как и системы местного управления, понимались по-разному властью и общественностью. Министр внутренних дел Н. А. Маклаков считал, что «городские самоуправления не могут быть освобождены от надзора правительственной власти, ибо это противоречило бы природе отношений между правительством и общественными учреждениями» $[25,824]$.

Известное раздражение у правительства вызывало стремление городских властей расширить сферу своей деятельности и выйти за пределы хозяйственных проблем. В разговоре с городским головой Петербурга И. И. Толстым Н. А. Маклаков заявил: «Городская дума - учреждение чисто хозяйственное, долженствующее стоять вне политики и социальных веяний». И. И. Толстой упоминает в дневнике (запись от 21 декабря 1913 г.), что вынужден был выслушать возмущение министра «заседаниями Городской думы, в которых обсуждалась реформа Городового положения, причем произносились чисто митинговые речи, напоминающие 1904 и 1905 годы». И далее он отмечал: «...министерства враждебно относились к “самоуправлениям” и желали им провала». Во время этой беседы Н. А. Маклаков заявил также о запрещении «по воле государя» проведения каких-либо манифестаций по поводу 50-летия земства. «Всякая манифестация, - заявил он, - хотя бы и самая небольшая, будет иметь роковые последствия не только для отдельных лиц, но и всего земского и городского управления» [26, 469, 673].

Вопрос о внесении изменений в действующее законодательство не сходил с повестки дня вплоть до 1917 г. Наиболее активно он обсуждался - «сдвинулся с мертвой точки» - в канун Первой мировой войны, когда общественность уделяла городской реформе «небывало мно- го внимания». «Русские города, - отмечалось в 1913 г., - только что пробуждаются к новой жизни, <...> над ними тяготеет невозможный закон, нежизненное, отсталое Положение 1892 г.» [27, 1264-1267].

Камнем преткновения между правительством и общественностью оставался вопрос об избирательном праве. Признавая возможным расширение круга избирателей, министр внутренних дел считал необходимым «сохранить руководство городским хозяйством в руках наиболее устойчивых и благонамеренных элементов населения» [25, 824]. Иными словами, правительство продолжало сохранять негативное отношение к городской интеллигенции и не допускало ее к избирательным урнам. Правда, в 1903 г. в Петербурге вступил в силу закон, позволявший съемщикам квартир, наряду с домовладельцами и предпринимателями, участвовать в выборах и быть избранными в гласные. Однако такое участие «интеллектуального элемента» было ограниченным и существовало только в северной столице. На основании положения от 8 июня 1903 г. «Об общественном управлении Санкт-Петербурга» избирательным правом среди квартиронанимателей могли пользоваться лишь лица, уплатившие квартирный налог в размере 33 руб. в год, что соответствовало годовой стоимости квартиры в 1000-1200 руб. [28, 645]. Таким высоким цензом от участия в выборах устранялись демократическая интеллигенция и рабочие. (Минимальный налог для владельцев недвижимости составлял 24 руб.)

Правительство, работая над новыми законопроектами городской и земской реформ, предполагало расширить социальное поле избирателей за счет квартиронанимателей во всех городах. Однако куриальная система выборов, против которой выступала общественность, сохранялась, власть городской управы усиливалась.

Отношение к избирательному праву, куриальной трехразрядной системе стало яблоком раздора среди депутатов - представителей разных партий в Государственной думе.

Прогрессисты и кадеты инициировали расширение круга избирателей за счет квартиронанимателей. Октябристы выступали за предоставление избирательного права всем плательщикам квартирного налога. Но, сохраняя куриальную систему, они тем самым сохраняли неравные условия для разных социальных слоев, отличавшихся имущественным цензом. 


\section{Исторический журнал: научные исследования № 4 (28) • 2015}

\section{DOI: $10.7256 / 2222-1972.2015 .4 .17038$}

Еще более консервативным был министерский проект, по которому избирательное право получили плательщики квартирного налога в размере налога с недвижимого имущества. При этом имущественный ценз, очень высокий по закону 1892 г. (3000 руб.), в столицах не понижался, а куриальная система сохранялась.

В одной из статей в журнале «Городское дело» отмечалось, что все эти варианты сохраняют «слабую <...> надежду на радикальную избирательную реформу, ожидающуюся из недр думских сфер» $[29,4,5]$.

Таким образом, в среде общественности, в том числе партийной, понимание необходимости расширения социально-имущественных границ избирательного права было («нынешнее избирательное право должно исчезнуть в наших городах в первую очередь»). Но вместе с этим было разное понимание решения этой проблемы, оставалось убеждение в невозможности введения в России всеобщего избирательного права, участия в выборах всех граждан, достигших 21 года, «учитывая реальное соотношение общественных сил настоящего времени» [30, 803, 804].

Вопрос о всеобщем избирательном праве отсутствовал в проекте городской реформы, составленном Главным комитетом Всероссийского союза городов (и опубликованном в 1917 г. в журнале «Третий элемент»), который наиболее полно отражал чаяния широких общественных кругов. (В более раннем и оставшемся неопубликованным проекте под названием «Основы муниципального избирательного права», составленном Комиссией при экономическом отделе Всероссийского союза городов не ранее 1915 г., также отсутствует упоминание о всеобщем избирательном праве для участия в муниципальных выборах [31, л. 1].)

В начале XX в. всеобщее избирательное право не существовало и в Западной Европе. Число граждан европейских городов, пользовавшихся избирательным правом, было разным, но сильно отличалось от российских реалий. Так, во Франции это число составляло $25 \%$, в Болгарии - 24\%, Испании - 23\%, Англии - 20\%, Баварии $-6-7 \%$, Саксонии - 5\%, России $-0,9 \%$ $[30,804]$.

Итак, годы обсуждения проблем городского законодательства, требующих изменений, не привели общество и правительство к разумному компромиссу. Не был найден подход к реформированию тех положений в законе 1892 г., кото- рые вносили бы коренные изменения в систему городского управления, расширяли социальное поле применения избирательного права - принципиально важного инструмента в процессе развития гражданской активности.

Пункт об избирательном праве отсутствовал в проекте кадетской партии, поступившем в Государственный совет в январе 1917 г. Он предусматривал расширение компетенции городской думы и управы, создание муниципальной полиции (чего долго добивался город) и «разнообразие по усмотрению города источников доходной части бюджета». Но в этом проекте городской реформы даже не было упоминания о сохранении или отмене административного контроля над органами местного самоуправления.

Временное правительство не отменило действие Городового положения 1892 г. «Временные правила о производстве выборов гласных городских дум...», введенные в апреле 1917 г., внесли в него лишь некоторые изменения, не затронув основные принципы. Как и прежде, сохранялось «удовлетворение потребностей воинского и гражданского управления, возложенное на город законом». Круг действий городского общественного управления ограничивался пределами города и отведенных ему земель. Сохранялся контроль правительственной администрации за деятельностью городской думы: «...в случае непризнания министром внутренних дел постановление думы считается недействительным» $[32$, л. 4, 9].

Первостепенная роль коронной администрации, во многом определявшая жизнь пореформенного города вплоть до начала XX в., совсем не исключала, а в ряде случаев и способствовала развитию города в России, в том числе - как центра креативной культуры. Одной из составляющих общественно-культурной городской среды столиц и провинциальных российских городов, наряду с образовательными, культурно-просветительными учреждениями, были довольно многочисленные общественные организации: научные, благотворительные, попечительные, сельскохозяйственные, пожарные общества, сословные и профессиональные организации, клубы для досуга и развлечений, занятий спортом, музыкальные кружки и т. п. [33; 34; 35]. Деятельность этих обществ, кружков, клубов являлась показателем самоорганизации городской общественности. Однако на практике активность таких 
общественных организаций была далеко не достаточной. «При строгой централизации управления жизнь общественная не могла вылиться в более или менее разнообразные формы: в Симбирской губернии, как и в других (курсив мой. - Л. К.), внешняя сторона жизни общества относительно государства проявлялась в формах, строго обусловленных общими государственными законоположениями» [36, 446]. Эта запись относится к концу 50-х гг. ХІХ в. Однако столь же значительная степень государственной опеки русского города практически сохранилась и в конце XIX - начале XX вв.

$\mathrm{O}$ «недостаточном развитии в городах общественных чувств» писал в конце XIX в. известный демократ, публицист Н. В. Шелгунов. «Необыкновенный успех в жизни городов сделали источники благ нематериальных, “изящные искусства” - театр и музыка, вообще зрелища <...> Повсюду в России $<\ldots>$ возникли в городах музыкальные общества, музыкальные кружки, даже симфонические общества». И далее он отмечал: «Городская интеллигенция образует вполне компетентную силу, если требуется оценить итальянскую оперу, но затем становится вполне некомпетентной, когда сталкивается с массой общественных явлений городской жизни <...> Общественное мнение <...> делается инертным и бессильным перед городской думою и управой» [37, 91, 92]. Подобное суждение можно встретить у Н. А. Рубакина, который заметил, что «русского читателя (речь идет о 1890-х гг. Л. К.) больше тянет в заоблачные сферы <...> объяснять непонятное, чем вырабатывать правильные понятия и размышлять об общественных делах» [38, 113].

Общественность активизируется в начале $\mathrm{XX}$ столетия, что было связано с изменениями в общественно-политической атмосфере в России кануна и времени революции 1905 г. Многие современники воспринимали происходящее как «начало нового практически жизненного и продуктивного настроения в жизни городской России», при этом отмечалось, что земства и города представляют собой «два наиболее крупных фактора местного самоуправления» $[39,4]$. В общественных кругах, периодике достаточно широко обсуждались эти проблемы. В Московском университете читались лекции по проблемам местного самоуправления, а в Коммерческом институте в Москве было создано отделение по местному самоуправлению и местному хозяйству «на основе изучения общественных, исторических, экономических и отчасти технических наук» [40, 1203].

События 1905-1907 гг. повлияли на активность избирателей при выборе гласных в городские думы. Заметен рост числа участвовавших в голосовании на выборах в городские думы в 1904 и 1908 гг. (в \%): в Москве - 20,8 и 39,7; в Вятке - 28,0 и 30,0; в Симбирске - 29,0 и 40,0. В Сызрани и Орле в 1908 г. в выборах участвовали более $50 \%$ горожан, имевших право голоса. Это были практические шаги в активизации общественности. Однако при «возросшей повсюду активности избирателей» в той же заметке в журнале «Городское дело» отмечалась «слабая сознательность, неопределенность избирателей в смысле отношения к программным вопросам городского дела» [41, 582].

Показателем гражданской активности стало появление новых форм общественной самодеятельности.

В России зарождаются профессиональные союзы. В движение за создание таких объединений вовлекается интеллигенция. В мае 1905 г. был создан Союз союзов, который объединил 14 профессиональных организаций в столицах и некоторых губернских городах. На первом собрании делегатов всероссийских профессиональных союзов присутствовали представители союзов адвокатов, журналистов и писателей, агрономов, ветеринаров, инженеров, учителей, фармацевтов, а также делегаты от союзов женского равноправия и равноправия евреев. Департамент полиции располагал агентурными сведениями о происходившем собрании [42, л. 35].

Программа этих профессиональных объединений имела достаточно радикальную общественно-политическую направленность. Борьбу «за политическое освобождение России на началах демократизма» Союз союзов провозгласил своей основной целью. «В настоящий исторический момент (май 1905 г., т. е. до издания Манифеста 17 октября. - Л. К.), - отмечалось в уставе этой организации, - борьба с существующим правительством за достижение свободы слова, печати, собраний, союзов, стачек и за созыв Учредительного собрания на основе всеобщего, равного, прямого и тайного голосования без различия пола, национальности и вероисповедания» является главным в деятельности Союза [43, л. 31, 34]. Таким образом, весной 1905 г. в среде общественности существовало понимание того, что «конституционный акт, опреде- 


\section{Исторический журнал: научные исследования № 4 (28) • 2015}

DOI: $10.7256 / 2222-1972.2015 .4 .17038$

лявший государственное устройство России, должен быть выработан Учредительным собранием» (резолюция III съезда адвокатов в феврале 1905 г.) [44, л. 3об.]. Осенью 1905 г. радикальные настроения проникли и в провинцию. Так, городской голова Самары призвал гласных добиваться созыва Учредительного собрания и закрыл заседание городской думы $[45,89]$.

Высочайший Манифест 17 октября 1905 г. включил некоторые из тезисов программы общественности, но, конечно, без той степени радикализма, которая присутствовала в документах Союза. Поэтому вполне объяснимо появление воззвания Бюро Союза союзов в день обнародования царского манифеста. Этот документ резко критикует правительственный акт, поскольку тот «делает лишь некоторые уступки народному движению, но не удовлетворяет неотложным требованиям». Среди последних упоминаются: созыв Учредительного собрания на основе всеобщего избирательного права, немедленное осуществление гражданских свобод, отмена законов, ограничивающих права отдельных национальностей, языков и религий $[46$, л. 1$]$.

Требование созыва Учредительного собрания на основе всеобщего избирательного права было лозунгом прогрессивной общественности, появившимся в условиях революционного возбуждения 1905 г. Оно встречается только в делах, относящихся к деятельности Союза союзов. В последующие годы в программах общественных организаций пункт о введении всеобщего избирательного права при выборах в представительные органы отсутствует (об этом речь шла выше).

Решение об изменении избирательного закона, «совершенно несоответствующего желаниям общества», было принято также на съезде городских и земских деятелей в сентябре 1905 г. в Москве [45, 89].

Однако Союз союзов просуществовал не более полугода: в 1906 г. в условиях спада революционного движения он практически прекратил существование.

Общественная атмосфера того времени повлияла на некоторые стороны жизни города. Одной из особенностей диалога города с властью становится большая открытость и разнообразие средств в обсуждении таких проблем городской жизни, как состояние инфраструктуры, муниципального хозяйства, финансы и бюджет, благотворительность, поиски форм объединения городов для решения общих для них вопросов. Они выносятся на страницы муниципальной периодики, появление которой было новацией в общественно-культурной жизни города. Такие журналы, как «Самоуправление» (1906-1907), «Вестник местного самоуправления» (1912), «Город. Вестник Всероссийского союза городов» (1917-1918), «Третий элемент» (1917), становятся средством формирования общественного мнения, несмотря на свою недолговечность. Единственным долгожителем среди муниципальных изданий был журнал Городское дело, выходивший в течение 9 лет (1909-1917). Редакторами-издателями его были Л. А. Велихов и М. П. Федоров - гласные Петербургской городской думы, члены кадетской партии. Среди авторов - многие авторитетные общественные и государственные деятели, ученые, врачи, инженеры, техники, архитекторы. Статьи в журнале печатали Д. Д Протопопов, К. К. Арсеньев, И. Х. Озеров, К. А. Пажитнов, Б. Б. Веселовский, П. Б. Струве и др.

Одной из форм самоорганизации общественности, как уже говорилось выше, были общества, разные по характеру своей деятельности. В рамках этих общественных организаций была сосредоточена интеллектуально-нравственная жизнь в городе, в какой-то мере способствовавшая и общественной инициативе, и гражданской ответственности.

Манифест 17 октября 1905 г., несмотря на критику его ограниченности со стороны радикальных сил, создавал условия для активизации общественности. Среди актов, изданных в продолжение провозглашенных манифестом свобод, был закон об обществах и союзах, опубликованный в марте 1906 г. [47]. Этот закон разрешал образовывать общества «без испрошения на то правительственной власти», но подчинял их Министерству внутренних дел. Воспрещались общества, имеющие политическую направленность, преследующие цели, «противные общественной нравственности <...> угрожающие общественному спокойствию» (ч. І, ст. 2, 3, 6).

Отдельная статья закона определяла характер деятельности профессиональных обществ, разрешаемых правительством с целью «согласования экономических интересов», «улучшения условий труда своих членов» (ч. II, ст. 1). Закон запрещал соединение профессиональных обществ в союз, а заявление о создании профсоюза, текст его устава «предъявлялись старшим фабричным инспектором губернатору или градоначальнику» (ч. II, ст. 6, 12). 
Таким образом, разрешив на волне огромного общественного подъема создание обществ, правительство ограничило появление обществ определенной общественно-политической направленности и сохранило контроль над их деятельностью. Вполне возможно, что прекращение деятельности Союза союзов в 1906 г. было связано не только со спадом революционных настроений, но с требованием закона, запрещавшего объединение обществ в союз.

Недолговечность появлявшихся в это время обществ, многие из которых были далеки от политических амбиций, в какой-то мере объяснялась действием закона 4 марта 1906 г. Среди таковых можно назвать общества обывателей и избирателей, существовавшие в Петербурге и некоторых губернских городах. Они занимались городским благоустройством, благотворительностью, просветительской работой.

Первое общество обывателей и избирателей появилось в Петербурге в конце 1906 г. Инициатива его создания принадлежала Г. А. Фальборку, гласному городской думы. В 1907-1908 гг. в северной столице существовало 15 таких обществ. Их члены знакомились с порядками городского хозяйства, здесь происходил обмен мнениями между гласными думы и их избирателями. Важно, что в работе этих обществ могли участвовать горожане, которые по закону не имели избирательных прав.

В Петербурге в обществах обывателей и избирателей участвовали многие представители интеллигенции: Д. Д. Протопопов - издатель, журналист, депутат I Государственной думы; А. Ф. Кони - известный адвокат, Л. А. Велихов редактор журнала «Городское дело», Н. А. Резцов и И. И. Толстой, занимавшие в разные годы должность городского головы. Подобные общества существовали в Смоленске, Рязани, Туле, Саратове, Омске, Иркутске, Красноярске, Одесce $[48,191 ; 1,82]$.

Правительство с самого начала рассматривало общества обывателей и избирателей как «затею кадетскую» и опасалось, что в «известный момент они займутся политической пропагандой, сыграют противоправительственную роль». В декабре 1909 г. Министерство внутренних дел затребовало от губернаторов сведения о «существовании подобных обществ в городах, его членах, особенно их партийной принадлежности». Большинство губернаторов высказались против таких обществ вообще, независимо от наличия их в городе. В циркуляре министра вну- тренних дел П. А. Столыпина губернаторам по поводу разрешения на открытие общества обывателей и избирателей в Елисаветграде (такое разрешение не последовало. - Л. К.) указывалось: «Имея в виду, что во многих местностях наблюдается стремление к учреждению подобных обществ, <..> покорнейше прошу <...> не допускать возникновения такого рода обществ, кои ставят задачей своей деятельности предметы, входящие в круг ведомства городских и земских установлений». На основании этого циркуляра началось закрытие обществ обывателей и избирателей. Первым было закрыто общество в Смоленске, затем 15 обществ в Петербурге. Запрещение обществ обывателей и избирателей, которые способствовали развитию «полезной и культурной самодеятельности» горожан, вызвало «единодушное осуждение» общественности не только в оппозиционных изданиях, но и в органе октябристов - «Голосе Москвы» [49].

Правительство, запрещая общества обывателей и избирателей, считало излишним участие общественных организаций даже в работе, далекой от острых политических проблем. «Выходит так, что в 20 веке в столице цивилизованного государства, легальное общество, <...> состоящее из “благонамереннейших" людей - тайных советников, домовладельцев, гласных думы, лишено права открыть на свои собственные деньги дешевую столовую!» «Политика, воспрещающая устройство детских площадок и дешевых столовых, - это политика варварства», - писал по этому поводу Л. А. Велихов [50, 521-522].

По поводу циркуляра министра внутренних дел о закрытии обществ обывателей и избирателей поступил запрос в Государственную думу. Однако комиссия Думы в своем решении отметила, что «находит издание министром внутренних дел упомянутого циркуляра закономерным и высказывается за отклонение запроса» $[21,472]$. Так закончилось противостояние правительства и общественности, пытавшейся найти новые формы своей общественно-полезной работы.

Не менее интересна история петербургского клуба общественных деятелей, открытие которого состоялось 14 октября 1905 г., за несколько дней до опубликования Манифеста 17 октября. Идея создания клуба возникла среди гласных Петербургской городской думы, принадлежавших к партии октябристов. Целью, как отмечалось в уставе, было «объединение общественных деятелей, чтобы облегчить им в кругу 


\section{Исторический журнал: научные исследования № 4 (28) • 2015}

DOI: $10.7256 / 2222-1972.2015 .4 .17038$

своих членов обсуждать возникающие в государственной жизни вопросы, а также общественные нужды и пользы» [51, л. 3; 4, 262-274].

Клуб общественных деятелей определял себя как беспартийную организацию, в него не допускались «представители крайних течений революции и реакции», «лица, принадлежавшие к партиям, признающим насильственные меры для торжества исповедуемых ими идей» [52, л. 1об.; 53, л. 1]. Он пользовался популярностью в Петербурге и вне его. Приезжавшие в столицу из других городов члены земских и городских собраний посещали заседания клуба по рекомендации одного из его членов. Со временем они могли стать его действительными членами. За два месяца работы клуба число его действительных членов составило 350 чел., его посетили более 150 чел. [52, л. 1].

Но даже организованный октябристами клуб был поставлен под контроль правительственной администрации: заседания устраивались «с предварительного в каждом случае разрешения подлежащей административной власти», градоначальник мог закрыть клуб, если в его заседании будет обнаружено «что-либо противное государственному порядку, общественной безопасности и нравственности». Так, к чтению в клубе были запрещены доклады, которые должны были состояться 14 марта 1906 г.: «О современном судопроизводстве и предполагаемых мерах его усовершенствования», «О положении рабочих в России, условиях страхования», «О новом законе об обществах и союзах» [51, л. 7,8$]$. Как отмечал один из членов клуба, «бытие обществ и союзов всецело зависит от усмотрения высших местных властей» [54, л. 3].

Среди проблем, интересовавших участников клуба общественных деятелей, была судьба реформы местного самоуправления. В мае 1907 г. председатель совета старейшин клуба М. В. Красовский в рамках обсуждения Городового положения 1892 г. выступил с докладом «Основы реформы местного самоуправления», в котором определил принципы такого реформирования. Речь шла об устранении сословности, привлечении к участию в местном управлении более широкого круга плательщиков земских и городских сборов, «имеющих оседлость в данной местности или недвижимое имущество».

Реформа, по мнению членов клуба, должна была исходить из необходимости «приспособления органов местного управления к новым формам государственного строя, упрочить в нашей народной жизни начала гражданской свободы, политического воспитания народа и подъема его благосостояния». Поднимался вопрос об устранении «излишней административной опеки». Однако, как считал М. В. Красовский, активный деятель партии октябристов, следовало сохранить ограничения в избирательной системе, и прежде всего - имущественно-налоговое начало: «...право голоса при выборах в органы местного самоуправления должно принадлежать только плательщикам налогов» [55, л. 1, 1об.]. Этот принцип избирательной системы нашел отражение в проекте нового Городового положения, поступившем в Государственную думу (о чем речь шла выше).

Новой формой общественной самодеятельности стали съезды городских деятелей (или городского благоустройства).

Вопрос о созыве съездов представителей городов впервые возник в 1891 г. Инициатором выступил городской голова г. Уфы. Идея была поддержана представителями других городов. Необходимость проведения городских съездов вызывалась прежде всего практическими потребностями развития муниципального хозяйства. Разобщенность в работе городских дум и невозможность обмена опытом становились серьезным препятствием. Но введение Городового положения 1892 г., сохранившего запрет действий городских властей вне пределов города, не благоприятствовало созыву подобных съездов.

Правительство, рассматривая эти съезды как разновидность местного самоуправления (в отличие, например, от многочисленных научных форумов того времени), видело в них «потенциальную опасность» для административной власти. По мнению деятелей городского управления, эти съезды являлись одним из средств «выработки положений, необходимых для нормальной городской жизни» [48, 161]. Они стали своеобразной формой объединения городов, что впоследствии в известной мере подготовило почву для возникновения Всероссийского союза городов.

Идея проведения съездов вновь возникла в первое десятилетие нового столетия в условиях активизации общественных сил, обсуждения Городового положения 1892 г. и необходимости внесения изменений в некоторые статьи этого закона.

Первый съезд городских деятелей состоялся в Одессе в сентябре 1910 г. Организатором 
выступило Одесское отделение Русского технического общества. Разрешение на проведение съезда давал министр внутренних дел. Такая практика сохранилась и при проведении последующих съездов.

Второй съезд проходил в Петербурге в декабре 1912 г. Его участниками были 300 делегатов из более 100 городов: работники городского управления, просветительских обществ, учебных заведений, земцы, депутаты Государственной думы, члены Государственного совета [56, 1087; 57, 661].

Из более чем 200 участников третьего съезда в Киеве в сентябре 1913 г. большинство составляли городские головы, гласные городских дум, члены городских управ 27 губернских и 63 уездных городов. В числе делегатов съезда были депутаты Государственной думы, представители Министерства внутренних дел, журналисты [27, 1264-1267]. Следующий съезд предполагался в Москве в 1914 г., но проведение съездов прервала начавшаяся Первая мировая война.

Программа съездов городских деятелей предусматривала прежде всего рассмотрение вопросов благоустройства, улучшения и развития муниципального хозяйства (транспорт, водопровод, канализация, народное здравоохранение). Однако были в ней и более общие для жизни города проблемы, возможность решения которых определялась степенью самостоятельности действий городских властей. Уже на съезде в Одессе поднимались вопросы об уменьшении административной опеки, о праве городов самостоятельно определять «смету доходов и расходов», о роли «общественного управления в деле устройства городов» [58].

В программе ставился вопрос о пересмотре Городового положения 1892 г., несмотря на нежелание Министерства внутренних дел допускать его обсуждение на съездах [59, 390]. В связи с предстоящим в Петербурге съездом Л. А. Велихов писал о необходимости для городов, «как хлеба насущного, многолюдного городского съезда с широкой программой, где бы можно было поднять свободный голос в защиту местной городской культуры, принижаемой опекой, вопиющими финансовыми условиями и всем устарелым городовым укладом» [57, 661].

Киевский съезд памятен тем, что в его программу был включен вопрос, обсуждавшийся в правительственных кабинетах: о взаимоотношении земства и городов, в том числе выделение городов из состава земств, о проведении совместных съездов этих общественных объединений [27, 1267].

Прошедшие в сентябре и ноябре 1905 г. совместные съезды земских и городских деятелей были последними - объединявшими городскую и земскую общественность. Попытка восстановить подобную практику в 1913 г. и провести съезд земских и городских деятелей оказалась безуспешной. Министерство внутренних дел запретило его проведение, мотивируя отказ тем, что «объединение земств и городов на таких съездах не предусмотрено». Л. А. Велихов справедливо усматривал основание этого «мотива» в нежелании правительства хоть в какой-то мере способствовать «объединению общественных сил, каковыми являлись земство и города» [60, 312-313]. Именно они составляли то социальнокультурное пространство, где наиболее успешно могла активизироваться общественность. Член кадетской партии, общественный деятель Н. И. Астров, уже находясь в эмиграции, анализируя общественно-политическую атмосферу «думского периода», писал: «...поход (правительства. - Л. К.) против земства есть поход против общественных самоуправлений. В этом <...> целая система политического действия, направленного к подавлению общественной самостоятельности в России» [61, 272-273].

Стремление к объединению земства и городов в рамках проведения совместных съездов было показателем консолидации общественности - одного из условий, определяющих состояние и степень развития гражданского общества. Негативное отношение правительства к этим действиям в известной мере определяло реальные возможности для формирования гражданского общества в дореволюционной России.

Некоторые изменения во взаимоотношения коронной администрации с общественностью внесла начавшаяся Первая мировая война. Она показала, что правительство нуждается в содействии городской общественности и земства в решении проблем военного времени, прежде всего - в организации помощи раненым и больным воинам.

Первая мировая война была фактором, во многом ускорившим общественно-политические процессы в жизни России. В годы войны усилилась та «невидимая работа», которая была важной и необходимой для развития гражданской активности $[62,2]$. В журнальных статьях неоднократно проводилась мысль, что война «вносит великие изменения в весь внутренний 


\section{Исторический журнал: научные исследования № 4 (28) • 2015}

\section{DOI: $10.7256 / 2222-1972.2015 .4 .17038$}

строй жизни страны», являясь «толчком, чтобы привести в движение общественные круги и заставить их понять, что один из выходов есть работа у корней жизни, бок о бок с обывателем, пробуждая и одухотворяя его» [63, 1169-1170]. В одной из статей в журнале «Городское дело» отмечалось, что «в страшных муках войны рождается новая Россия» [30, 802].

Всероссийский союз городов (ВСГ), появившийся в самом начале войны, был одним из проявлений этого «движения».

Решение о создании Союза городов было принято на Первом всероссийском съезде городских голов в Москве 9 августа 1914 г. Создание ВСГ происходило на волне «единения» общества с властью, которое охватило страну в первые дни войны. На встрече Николая II с делегацией городских голов, состоявшейся в Кремлевском дворце еще до начала учредительного съезда, московский городской голова В. Д. Брянцев говорил о «чувстве любви и преданности», о том, что «города России сливаются в единый союз в деле оказания помощи воинам Вашим» $[64,6]$. Незадолго до этого, 30 июля, было объявлено об организации Всероссийского земского союза. Уже 12 августа 1914 г. правительство официально санкционировало создание этих союзов $[65,3]$.

Появление ВСГ в годы войны было осуществлением идеи объединения городов, которая «давно витает в воздухе у нас в России», как отмечал И. И. Толстой в заметке, опубликованной в «Биржевых новостях» в сентябре 1914 г.

Однако правительство, разрешив создание Союза городов, не одобряло полностью подобную форму общественной самоорганизации и смотрело с недоверием на появление этого общественного объединения.

С самого начала власть и общественность по-разному представляли задачи и деятельность ВСГ. Уже на первом учредительном съезде делегатам сообщили, что министр внутренних дел Н. А. Маклаков разрешил съезд (а следовательно, и создание Союза городов) «исключительно для обсуждения проблем помощи раненым» [66, 1144]. Маклаков считал, что сфера компетенции Союза городов, как и Земского союза, не должна выходить за эти пределы. Деятели Союза городов понимали свою работу гораздо шире: «Правительство надеялось, что союз основывается ad hoc (для данного момента. - Л. К.) и что с прекращением войны можно будет поговорить еще о том, существовать ли ему дальше или нет. Приехавшие в Москву городские головы, напротив того, с большим единодушием высказались за желательность и даже необходимость существования такого союза как постоянного института», - записал в дневнике И. И. Толстой [26, 535-536].

Учредители ВСГ, признавая первостепенной задачей оказание помощи раненым, все же рассматривали свою деятельность более широко и прежде всего считали, что Союз городов должен содействовать «прочной связи городов», способствовать «изысканию способов и средств для оказания помощи городам в общих их нуждах и потребностях». Об этом Н. И. Астров говорил уже на первом съезде в сентябре 1914 г., подчеркивая при этом необходимость объединенной работы Союза городов и Всероссийского земского союза [64, 8-9].

Всероссийские съезды Союза городов (за недолгое время его существования состоялось семь съездов) объединяли широкие общественные силы. Среди участников первого съезда ВСГ были городские головы 40 губернских центров, члены Земского союза, Красного Креста, военной миссии Москвы. В последующих съездах принимали участие гласные городских дум, депутаты Государственной думы, промышленники, научная интеллигенция. Среди них: Н. И. Астров, гласный Московской городской думы, а затем городской голова в марте-июле 1917 г.; С. В. Бахрушин, историк, впоследствии профессор Московского университета, в то время - редактор журнала «Известия Всероссийского союза городов помощи больным и раненым воинам»; М. М. Новиков, профессор, ректор Московского университета в 19191920 гг.; предприниматели П. А. Бурышкин, Л. Л. Катуар; Г. И. Шрейдер, публицист, член партии эсеров, городской голова Петрограда в сентябре-ноябре 1917 г.

Численно Всероссийский союз городов рос достаточно быстро за счет не только губернских, но и уездных городов. В августе 1914 г. в него вошли 140 городов, через месяц их число увеличилось до 196, в ноябре - до 272 (из них 201 уездный город). В начале 1915 г. союз объединял около 400, а в августе 1917 г. - 630 городов $[64,15 ; 67,64 ; 68,3 ; 69,5]$.

Деятели ВСГ в массе своей принадлежали к партии конституционных демократов. Это и определило постепенно нараставшую оппозиционность данной организации. Выступая в октябре 1917 г. на очередном съезде ВСГ, 
Н. И. Астров заявил, что «союзы (имеются в виду земств и городов. - Л. К.) были явлением политической жизни, несовместимой с самодержавным строем» $[69,1]$.

Рост оппозиционности ВСГ правительство отнюдь не приветствовало. Еще в 1914 г., в самом начале деятельности Союза городов, Н. А. Маклаков в записке в Совет министров отмечал, что «союзы (ВСГ и ВЗС. - Л. К.) не мирятся с временным характером своей деятельности и определенно готовятся к той работе по переустройству общественной жизни, очередь которой, по их мнению, должна наступить после благополучного окончания войны» $[3,22]$.

Стремительно развивающаяся общественно-политическая жизнь в России в 1917 г. определила и судьбу Всероссийского союза городов. VII съезд ВСГ, проходивший 14-16 октября
1917 г., подтвердил необходимость сохранения этой общественной организации $[70,2]$. Однако после Октября 1917 г. деятельность ВСГ практически прекратилась. В июне 1918 г. Всероссийский союз городов и Земский союз были упразднены законодательно.

Последние предреволюционные десятилетия в общественно-политической жизни России были временем консолидации общественности, усиления гражданской активности, появления разных форм общественной самодеятельности помимо существовавших партийных объединений. Особенностью российской жизни было практически постоянное противодействие официальной власти появлению и развитию этих форм общественной самоорганизации. В конечном итоге это определило безуспешность диалога власти и общества в дореволюционной России.

\section{Библиография:}

1. Туманова А. С. Общественные организации и русская публика в начале XX в. М.: Новый хронограф, 2007. 320 с.

2. Самоорганизация российской общественности в последней трети XVIII - начале XX в. / Отв. ред. А. С. Туманова. М.: РОССПЭН, 2011. 886 с

3. Шевырин В. М. Земский и Городской союзы (1914-1917): Аналитический обзор. М.: Институт научной информации по общественным наукам, 2000. $63 \mathrm{c}$.

4. Розенталь И. С. «И вот общественное мненье!» Клубы в истории российской общественности. Конец XVIII - начало XX в. М.: Новый хронограф, 2007. 398 с.

5. Розенталь И. С. Политические клубы, кружки, салоны // Очерки русской культуры. Конец XIX - начало XX века. Т. 2. Власть. Общество. Культура. М.: Издательство Московского университета, 2011. С. 161-201.

6. Кошман Л. В. Власть и город. Судьбы местного самоуправления // Очерки русской культуры. Конец XIX - начало ХХ века. Т. 2. Власть. Общество. Культура. М.: Издательство Московского университета, 2011. С. 469-517.

7. Щепкин М. П. Общественное самоуправление в Москве: Проект городского положения М. П. Щепкина. М.: Товарищество скоропечатни А. А. Левенсона, 1906.181 с.

8. Городовое положение 16 июня 1870 г. // Полное собрание законов Российской империи. Собр. 2-е. T. XLV. Отд. 1. CПб.: Тип. II Отделения собств. е. и. в. канцелярии, 1874. № 48498. С. 821-839.

9. Городовое положение со всеми относящимися к нему узаконениями, судебными и правительственными разъяснениями / Сост. М. И. Мыш. СПб.: Типография Н. А. Лебедева, 1876. 160 с.

10. Городовое положение 11 июня 1892 г. // Полное собрание законов Российской империи. Собрание 3-е. Т. XII. СПб.: Государственная типография, 1895. № 8708. С. 430-456.

11. Городовое положение 11 июня 1892 г. с относящимися к нему узаконениями, судебными и правительственными разъяснениями / Сост. М. И. Мыш. СПб.: Типография В. Г. Авсеенко, 1893. XVI, 787 с.

12. Гессен В. М. Городское самоуправление: Дополнение к курсу русского государственного права. СПб.: Касса взаимопомощи студентов Санкт-Петербургского политехнического института императора Петра Великого, 1912. 27 c.

13. Михайловский А. Г. Реформа городского самоуправления в России. М.: Польза, 1908. 109 с.

14. Нардова В. А. Городское самоуправление в России в $60-\mathrm{x}$ - начале 90 -х годов XIX в. Правительственная политика. Л.: Наука, Ленинградское отделение, 1984. 260 с.

15. Шрейдер Г. И. Городская контрреформа 11 июня 1892 г. // История России в XIX веке: В 9 т. СПб.: А. и И. Гранат, 19071911. Т. 5. СПб., 1909. С. 181-228.

16. Материалы, относящиеся до нового общественного устройства в городах Империи: В 6 т. Т. 3. СПб.: Хозяйственный департамент Министерства внутренних дел, 1877. 515 с.

17. Гессен В. М. Вопросы местного управления. СПб.: Книжный склад «Право», 1904. 235 с.

18. Нардова В. А. Самодержавие и городские думы в России в конце XIX - начале XX в. СПб.: Наука, 1994. 157 с.

19. Писарькова Л. В. Городские реформы в России и Московская дума. М.: Новый хронограф; АИРО-ХXI, 2010. 735 с.

20. Озеров И. Х. Большие города, их задачи и средства управления. М.: Типография Министерства финансов (В. Киршбаума), 1906. $52 \mathrm{c.}$

21. Законодательная хроника // Городское дело. 1911. № 5. С. 470-472.

22. Пажитнов К. А. Городское и земское самоуправление. СПб.: М. И. Семенов, 1913. 144 с.

23. Кизеветтер А. А. На рубеже двух столетий. Воспоминания. 1881-1914. М.: Искусство, 1997. 395 с.

24. Две реформы // Городское дело. 1916. № 4. С. 159-163. 


\section{Исторический журнал: научные исследования № 4 (28) • 2015}

DOI: $10.7256 / 2222-1972.2015 .4 .17038$

25. [Гибшман А. М.] Муниципальное обозрение // Городское дело. 1913. № 11-12. С. 820-829.

26. Толстой И. И. Дневник. 1906-1916. СПб.: Фонд регионального развития Санкт-Петербурга, 1997.728 с.

27. Протопопов Д. Д. Киевский первый всероссийский съезд городских деятелей // Городское дело. 1913. № 19. С. $1260-1288$.

28. Положение об общественном управлении города Санкт-Петербурга 8 июня 1903 г. // Полное собрание законов Российской империи. Собрание 3-е. Т. XII. СПб.: Государственная типография, 1905. № 23101. С. 641-660.

29. Петров М. Избирательное право в существующих проектах реформы Городового положения // Городское дело. 1917. № 1. С. 4-6.

30. Андреев Ник. Вопиющее противоречие // Городское дело. 1915. № 15-16. С. 802-807.

31. Государственный архив Российской Федерации (ГА РФ). Ф. 518. Союз городов. Оп. 1. Д. 194.

32. Государственный архив Российской Федерации (ГА РФ). Ф. 1789. Главное управление по делам местного хозяйства Министерства внутренних дел Временного правительства. Оп. 2. Д. 5.

33. Вся Россия: [Обзор]. Особое приложение к газете «Россия». № 8. СПб.: Типография газеты «Россия», 1905. [2], 9-800 стб.

34. Анохина Л. А., Шмелева М. Н. Быт городского населения средней полосы РСФСР в прошлом и настоящем. На примере городов Калуга, Елец, Ефремов. М.: Наука, 1977. 358 с.

35. Иванов Ю. А. Уездная Россия: местные власти, церковь и общество во второй половине XIX - начале XX в. Иваново: Издательство Ивановского государственного университета, 2003. 268 с.

36. Материалы для географии и статистики России, собранные офицерами Генерального штаба: В 32 т. Т. 20. Ч. 2 . Симбирская губерния. СПб.: Главное управление Генерального штаба, 1868. 761 с.

37. Шелгунов Н. В. Очерки русской жизни («Русские ведомости», 1885 г., «Русская мысль», 1886-1891 г.). СПб.: 0. Н. Попова, 1895. 1098 стб.

38. Рубакин Н. А. Этюды о русской читающей публике: Факты, цифры и наблюдения. СПб.: Книжный магазин Карбасникова, 1895. 245 с.

39. От редакции // Вестник местного самоуправления. 1912. № 1. С. 1-5.

40. Д. П. Из Москвы // Городское дело. 1909. № 22. С. 1203-1205.

41. Хижняков В. В. Городские выборы // Городское дело. 1909. № 12. С 578-586.

42. Государственный архив Российской Федерации (ГА РФ). Ф. 102. Департамент полиции. Особый отдел. Оп. 233 а. Д. 999.

43. Государственный архив Российской Федерации (ГА РФ). Ф. 518. Союз городов. Оп. 1. Д. 1.

44. Государственный архив Российской Федерации (ГА РФ). Ф. 518. Союз городов. Оп. 1. Д. 28.

45. Тюрин В. А. Власть и городское самоуправление в Среднем Поволжье: опыт взаимодействия на рубеже ХІХ-ХХ веков. Самара: Издательство «Самарский университет», 2007. 200 с.

46. Государственный архив Российской Федерации (ГА РФ). Ф. 518. Союз городов. Оп. 1. Д. 6.

47. О временных правилах об обществах и союзах. Именной Высочайший указ, данный Сенату 4 марта 1906 г. // Полное собрание законов Российской империи. Собрание 3-е. T. XXVI. Отд. 1. СПб.: Государственная типография, 1909. № 27479. C. 201-207.

48. Петербургская городская дума. 1846-1918. СПб.: Лики России, 2005. 541 с.

49. Велихов Л. А. Общества обывателей и избирателей // Городское дело. 1910. № 18. С. 1262-1267.

50. Велихов Л. А. Смесь // Городское дело. 1910. № 8. С. 521-530.

51. Государственный архив Российской Федерации (ГА РФ). Ф. 1820. Петербургский клуб общественных деятелей. Оп. 1. Д. 1.

52. Государственный архив Российской Федерации (ГА РФ). Ф. 1820. Петербургский клуб общественных деятелей. Оп. 1. Д. 9.

53. Государственный архив Российской Федерации (ГА РФ). Ф. 1820. Петербургский клуб общественных деятелей. Оп. 1. Д. 10.

54. Государственный архив Российской Федерации (ГА РФ). Ф. 1820. Петербургский клуб общественных деятелей. Оп. 1. Д. 7.

55. Государственный архив Российской Федерации (ГА РФ). Ф. 1820. Петербургский клуб общественных деятелей. Оп. 1. Д. 14.

56. Муниципальное обозрение. К предстоящему съезду городов // Городское дело. 1912. № 17. С. $1085-1088$.

57. Муниципальное обозрение. О предстоящем съезде городов // Городское дело. 1912. № 10. С. 660-661.

58. Программа первого съезда по благоустройству городов // Городское дело. 1910. № 9. С. 600-601.

59. Съезды городских представителей. К пересмотру Городового положения // Городское дело. 1912. № 6. С. $389-393$.

60. Велихов Л. А. Муниципальное обозрение // Городское дело. 1913. № 5. С. 312-316.

61. Астров Н. И. Воспоминания. Париж: ҮМКА-Пресс, 1940. Т. 1. 359 с.

62. Астров Н. И. Деятельность городов, вызванная нуждами военного времени: Доклад 2-му съезду Союза городов // Известия Всероссийского Союза городов помощи больным и раненым воинам. 1915. № 10. С. 1-12.

63. Один из путей // Городское дело. 1915. № 22. С. 1167-1170.

64. Всероссийский Союз городов. Краткий исторический очерк возникновения и развития // Известия Всероссийского Союза городов помощи больным и раненым воинам. 1914. № 1. С. 3-28.

65. Погребинский А. П. К истории союзов земств и городов в годы империалистической войны // Исторические записки. [Т.] 12. М.: АН СССР, 1941. С. 39-60.

66. Протопопов Д. Д. Первый съезд Всероссийского общегородского союза // Городское дело. 1914. № 19. С. 1141-1150.

67. Деятельность Главного комитета Всероссийского Союза городов // Известия Всероссийского Союза городов помощи больным и раненым воинам. 1914. № 1. С. 41-64.

68. Второй съезд Всероссийского Союза городов помощи больным и раненым воинам // Известия Всероссийского Союза городов помощи больным и раненым воинам. 1915. № 8. С. 3-32.

69. Астров Н. И. Доклад Главного комитета Всероссийского Союза городов об организации Союза. В надзаг.: 7-й съезд Всерос. Союза городов 14/16 окт. 1917 г. [М.: Б. и., 1917]. 18 с.

70. Астров Н. И. VII съезд Союза городов // Город. Вестник Всероссийского Союза городов. 1917. № 8. С. 2-3 


\section{References (transliterated):}

1. Tumanova A. S. Obshchestvennye organizatsii i russkaya publika v nachale KhKh v. M.: Novyi khronograf, 2007. 320 s.

2. Samoorganizatsiya rossiiskoi obshchestvennosti v poslednei treti XVIII - nachale KhKh v. / Otv. red. A. S. Tumanova. M.: ROSSPEN, 2011. $886 \mathrm{~s}$.

3. Shevyrin V. M. Zemskii i Gorodskoi soyuzy (1914-1917): Analiticheskii obzor. M.: Institut nauchnoi informatsii po obshchestvennym naukam, 2000.63 s.

4. Rozental' I. S. «I vot obshchestvennoe mnen'e!» Kluby v istorii rossiiskoi obshchestvennosti. Konets XVIII - nachalo KhKh v. M.: Novyi khronograf, 2007.398 s.

5. Rozental' I. S. Politicheskie kluby, kruzhki, salony // Ocherki russkoi kul'tury. Konets XIX - nachalo KhKh veka. T. 2. Vlast'. Obshchestvo. Kul'tura. M.: Izdatel'stvo Moskovskogo universiteta, 2011. S. 161-201.

6. Koshman L. V. Vlast' i gorod. Sud'by mestnogo samoupravleniya // Ocherki russkoi kul'tury. Konets XIX - nachalo KhKh veka. T. 2. Vlast'. Obshchestvo. Kul'tura. M.: Izdatel'stvo Moskovskogo universiteta, 2011. S. 469-517.

7. Shchepkin M. P. Obshchestvennoe samoupravlenie v Moskve: Proekt gorodskogo polozheniya M. P. Shchepkina. M.: Tovarishchestvo skoropechatni A. A. Levensona, 1906.181 s.

8. Gorodovoe polozhenie 16 iyunya 1870 g. // Polnoe sobranie zakonov Rossiiskoi imperii. Sobr. 2-e. T. XLV. Otd. 1. SPb.: Tip. II Otdeleniya sobstv. e. i. v. kantselyarii, 1874. № 48498. S. 821-839.

9. Gorodovoe polozhenie so vsemi otnosyashchimisya k nemu uzakoneniyami, sudebnymi i pravitel'stvennymi raz"yasneniyami / Sost. M. I. Mysh. SPb.: Tipografiya N. A. Lebedeva, 1876.160 s.

10. Gorodovoe polozhenie 11 iyunya 1892 g. // Polnoe sobranie zakonov Rossiiskoi imperii. Sobranie 3-e. T. XII. SPb.: Gosudarstvennaya tipografiya, 1895. № 8708. C. 430-456.

11. Gorodovoe polozhenie 11 iyunya 1892 g. s otnosyashchimisya k nemu uzakoneniyami, sudebnymi i pravitel'stvennymi raz"yasneniyami / Sost. M. I. Mysh. SPb.: Tipografiya V. G. Avseenko, 1893. XVI, 787 s.

12. Gessen V. M. Gorodskoe samoupravlenie: Dopolnenie k kursu russkogo gosudarstvennogo prava. SPb.: Kassa vzaimopomoshchi studentov Sankt-Peterburgskogo politekhnicheskogo instituta imperatora Petra Velikogo, 1912. $27 \mathrm{~s}$.

13. Mikhailovskii A. G. Reforma gorodskogo samoupravleniya v Rossii. M.: Pol'za, 1908. $109 \mathrm{~s}$

14. Nardova V. A. Gorodskoe samoupravlenie v Rossii v 60-kh - nachale 90-kh godov XIX v. Pravitel'stvennaya politika. L.: Nauka, Leningradskoe otdelenie, 1984. $260 \mathrm{~s}$.

15. Shreider G. I. Gorodskaya kontrreforma 11 iyunya 1892 g. // Istoriya Rossii v XIX veke: V 9 t. SPb.: A. i I. Granat, 1907-1911. T. 5. SPb., 1909. S. 181-228.

16. Materialy, otnosyashchiesya do novogo obshchestvennogo ustroistva v gorodakh Imperii: V 6 t. T. 3. SPb.: Khozyaistvennyi departament Ministerstva vnutrennikh del, $1877.515 \mathrm{~s}$.

17. Gessen V. M. Voprosy mestnogo upravleniya. SPb.: Knizhnyi sklad «Pravo», 1904. $235 \mathrm{~s}$.

18. Nardova V. A. Samoderzhavie i gorodskie dumy v Rossii v kontse XIX - nachale KhKh v. SPb.: Nauka, 1994. $157 \mathrm{s.}$

19. Pisar'kova L. V. Gorodskie reformy v Rossii i Moskovskaya duma. M.: Novyi khronograf; AIRO-XXI, 2010. 735 s.

20. Ozerov I. Kh. Bol'shie goroda, ikh zadachi i sredstva upravleniya. M.: Tipografiya Ministerstva finansov (V. Kirshbauma), $1906.52 \mathrm{~s}$.

21. Zakonodatel'naya khronika // Gorodskoe delo. 1911. № 5. S. 470-472.

22. Pazhitnov K. A. Gorodskoe i zemskoe samoupravlenie. SPb.: M. I. Semenov, 1913. $144 \mathrm{~s}$.

23. Kizevetter A. A. Na rubezhe dvukh stoletii. Vospominaniya. 1881-1914. M.: Iskusstvo, 1997. $395 \mathrm{~s}$.

24. Dve reformy // Gorodskoe delo. 1916. № 4. S. 159-163.

25. [Gibshman A. M.] Munitsipal'noe obozrenie // Gorodskoe delo. 1913. № 11-12. S. 820-829.

26. Tolstoi I. I. Dnevnik. 1906-1916. SPb.: Fond regional'nogo razvitiya Sankt-Peterburga, 1997. 728 s.

27. Protopopov D. D. Kievskii pervyi vserossiiskii s"ezd gorodskikh deyatelei // Gorodskoe delo. 1913. № 19. S. 1260-1288.

28. Polozhenie ob obshchestvennom upravlenii goroda Sankt-Peterburga 8 iyunya 1903 g. // Polnoe sobranie zakonov Rossiiskoi imperii. Sobranie 3-e. T. XII. SPb.: Gosudarstvennaya tipografiya, 1905. № 23101. S. 641-660.

29. Petrov M. Izbiratel'noe pravo v sushchestvuyushchikh proektakh reformy Gorodovogo polozheniya // Gorodskoe delo. 1917. № 1. S. 4-6.

30. Andreev Nik. Vopiyushchee protivorechie // Gorodskoe delo. 1915. № 15-16. S. 802-807.

31. Gosudarstvennyi arkhiv Rossiiskoi Federatsii (GA RF). F. 518. Soyuz gorodov. Op. 1. D. 194

32. Gosudarstvennyi arkhiv Rossiiskoi Federatsii (GA RF). F. 1789. Glavnoe upravlenie po delam mestnogo khozyaistva Ministerstva vnutrennikh del Vremennogo pravitel'stva. Op. 2. D. 5.

33. Vsya Rossiya: [Obzor]. Osoboe prilozhenie k gazete «Rossiya». № 8. SPb.: Tipografiya gazety «Rossiya», 1905. [2], 9-800 stb.

34. Anokhina L. A., Shmeleva M. N. Byt gorodskogo naseleniya srednei polosy RSFSR v proshlom i nastoyashchem. Na primere gorodov Kaluga, Elets, Efremov. M.: Nauka, 1977. $358 \mathrm{s.}$

35. Ivanov Yu. A. Uezdnaya Rossiya: mestnye vlasti, tserkov' i obshchestvo vo vtoroi polovine XIX - nachale KhKh v. Ivanovo: Izdatel'stvo Ivanovskogo gosudarstvennogo universiteta, 2003. $268 \mathrm{s.}$

36. Materialy dlya geografii i statistiki Rossii, sobrannye ofitserami General'nogo shtaba: V 32 t. T. 20. Ch. 2. Simbirskaya guberniya. $\mathrm{SPb} .:$ Glavnoe upravlenie General'nogo shtaba, 1868. $761 \mathrm{~s}$.

37. Shelgunov N. V. Ocherki russkoi zhizni («Russkie vedomosti», 1885 g., «Russkaya mysl'», 1886-1891 g.). SPb.: 0. N. Popova, 1895. 1098 stb.

38. Rubakin N. A. Etyudy o russkoi chitayushchei publike: Fakty, tsifry i nablyudeniya. SPb.: Knizhnyi magazin Karbasnikova, 1895. $245 \mathrm{~s}$.

39. Ot redaktsii // Vestnik mestnogo samoupravleniya. 1912. № 1. S. 1-5. 


\section{Исторический журнал: научные исследования № 4 (28) • 2015}

DOI: $10.7256 / 2222-1972.2015 .4 .17038$

40. D. P. Iz Moskvy // Gorodskoe delo. 1909. № 22. S. 1203-1205.

41. Khizhnyakov V. V. Gorodskie vybory // Gorodskoe delo. 1909. № 12. S 578-586.

42. Gosudarstvennyi arkhiv Rossiiskoi Federatsii (GA RF). F. 102. Departament politsii. Osobyi otdel. Op. 233a. D. 999.

43. Gosudarstvennyi arkhiv Rossiiskoi Federatsii (GA RF). F. 518. Soyuz gorodov. Op. 1. D. 1.

44. Gosudarstvennyi arkhiv Rossiiskoi Federatsii (GA RF). F. 518. Soyuz gorodov. Op. 1. D. 28.

45. Tyurin V. A. Vlast' i gorodskoe samoupravlenie v Srednem Povolzh'e: opyt vzaimodeistviya na rubezhe XIX-KhKh vekov. Samara: Izdatel'stvo «Samarskii universitet», 2007. $200 \mathrm{~s}$.

46. Gosudarstvennyi arkhiv Rossiiskoi Federatsii (GA RF). F. 518. Soyuz gorodov. Op. 1. D. 6.

47. O vremennykh pravilakh ob obshchestvakh i soyuzakh. Imennoi Vysochaishii ukaz, dannyi Senatu 4 marta 1906 g. // Polnoe sobranie zakonov Rossiiskoi imperii. Sobranie 3-e. T. XXVI. Otd. 1. SPb.: Gosudarstvennaya tipografiya, 1909. № 27479. S. $201-207$.

48. Peterburgskaya gorodskaya duma. 1846-1918. SPb.: Liki Rossii, 2005. $541 \mathrm{s.}$

49. Velikhov L. A. Obshchestva obyvatelei i izbiratelei // Gorodskoe delo. 1910. № 18. S. 1262-1267.

50. Velikhov L. A. Smes' // Gorodskoe delo. 1910. № 8. S. 521-530.

51. Gosudarstvennyi arkhiv Rossiiskoi Federatsii (GA RF). F. 1820. Peterburgskii klub obshchestvennykh deyatelei. Op. 1. D. 1.

52. Gosudarstvennyi arkhiv Rossiiskoi Federatsii (GA RF). F. 1820. Peterburgskii klub obshchestvennykh deyatelei. Op. 1. D. 9.

53. Gosudarstvennyi arkhiv Rossiiskoi Federatsii (GA RF). F. 1820. Peterburgskii klub obshchestvennykh deyatelei. Op. 1. D. 10.

54. Gosudarstvennyi arkhiv Rossiiskoi Federatsii (GA RF). F. 1820. Peterburgskii klub obshchestvennykh deyatelei. Op. 1. D. 7.

55. Gosudarstvennyi arkhiv Rossiiskoi Federatsii (GA RF). F. 1820. Peterburgskii klub obshchestvennykh deyatelei. Op. 1. D. 14.

56. Munitsipal'noe obozrenie. K predstoyashchemu s"ezdu gorodov // Gorodskoe delo. 1912. № 17. S. 1085-1088.

57. Munitsipal'noe obozrenie. 0 predstoyashchem s"ezde gorodov // Gorodskoe delo. 1912. № 10. S. 660-661.

58. Programma pervogo s"ezda po blagoustroistvu gorodov // Gorodskoe delo. 1910. № 9. S. 600-601.

59. S"ezdy gorodskikh predstavitelei. K peresmotru Gorodovogo polozheniya // Gorodskoe delo. 1912. № 6. S. 389-393.

60. Velikhov L. A. Munitsipal'noe obozrenie // Gorodskoe delo. 1913. № 5. S. 312-316.

61. Astrov N. I. Vospominaniya. Parizh: YMKA-Press, 1940. T. 1. $359 \mathrm{~s}$.

62. Astrov N. I. Deyatel'nost' gorodov, vyzvannaya nuzhdami voennogo vremeni: Doklad 2-mu s"ezdu Soyuza gorodov // Izvestiya Vserossiiskogo Soyuza gorodov pomoshchi bol'nym i ranenym voinam. 1915. № 10. S. 1-12.

63. Odin iz putei // Gorodskoe delo. 1915. № 22. S. 1167-1170.

64. Vserossiiskii Soyuz gorodov. Kratkii istoricheskii ocherk vozniknoveniya i razvitiya // Izvestiya Vserossiiskogo Soyuza gorodov pomoshchi bol'nym i ranenym voinam. 1914. № 1. S. 3-28.

65. Pogrebinskii A. P. K istorii soyuzov zemstv i gorodov v gody imperialisticheskoi voiny // Istoricheskie zapiski. [T.] 12. M.: AN SSSR, 1941. S. 39-60.

66. Protopopov D. D. Pervyi s"ezd Vserossiiskogo obshchegorodskogo soyuza // Gorodskoe delo. 1914. № 19. S. 1141-1150.

67. Deyatel'nost' Glavnogo komiteta Vserossiiskogo Soyuza gorodov // Izvestiya Vserossiiskogo Soyuza gorodov pomoshchi bol'nym i ranenym voinam. 1914. № 1. S. 41-64.

68. Vtoroi s"ezd Vserossiiskogo Soyuza gorodov pomoshchi bol'nym i ranenym voinam // Izvestiya Vserossiiskogo Soyuza gorodov pomoshchi bol'nym i ranenym voinam. 1915. № 8. S. 3-32.

69. Astrov N. I. Doklad Glavnogo komiteta Vserossiiskogo Soyuza gorodov ob organizatsii Soyuza. V nadzag.: 7-i s"ezd Vseros. Soyuza gorodov 14/16 okt. 1917 g. [M.: B. i., 1917]. $18 \mathrm{~s}$.

70. Astrov N. I. VII s"ezd Soyuza gorodov // Gorod. Vestnik Vserossiiskogo Soyuza gorodov. 1917. № 8. S. 2-3. 